\title{
THE DIFFICULT PROBLEM OF GROWING ATHLETES AMONG WOMEN LIVING IN RURAL AREAS AND BORDER TERRITORIES OF THE REPUBLIC OF UZBEKISTAN
}

\section{Tolametov A.A.}

Acting Associate Professor, Department of Pedagogy And Psychology, Institute Of Retraining And Advanced Training Of Specialists In Physical Culture And Sports, Uzbekistan

Yusupkhanova F.A.

Teacher, Department of Social Sciences, Institute Of Retraining And Advanced Training Of Physical Culture And Sports, Uzbekistan

\section{ABSTRACT}

The article discusses the current problems of the development of female athletes in rural areas, remote and remote areas of the Republic of Uzbekistan.

KEYWORDS:- Sports, family, family upbringing, talented athletes, healthy generation, physical culture.

\section{INTRODUCTION}

Relevance. Resolution of the President of the Republic of Uzbekistan dated June 27, 2018 No PP-3808 "On approval of the Concept of strengthening the family in the Republic of Uzbekistan" and February 2, 2018 "On measures to radically improve the activities in support of women and strengthening the family One of the priorities of our society is the implementation of the goals and objectives set out in the Decree No. PF-5325 [2,3].

Today, sport is becoming an important component of socio-economic development, spiritual and cultural life. After all, sport is a physical and educational phenomenon that quickly introduces the nation to the people. Therefore, it is no coincidence that the fourth priority area of the "Strategy for further development of the Republic of Uzbekistan" for 2017-2021, focused on "Development of the social sphere", pays special attention to improving the science, education, literature, art and sports. In order to implement the practical aspects of these issues, the President of the Republic of Uzbekistan adopted a resolution on June 3, 2017, which reads: There are important and urgent tasks to protect against harmful habits, to create the necessary conditions for them to realize their abilities and talents, to select talented athletes and to improve the system of targeted training. [2].

If we look at this problem on the basis of the 
CURRENT RESEARCH JOURNAL OF PEDAGOGICS 2(9): 136-141,

September 2021 DOI: https://doi.org/10.37547/pedagogics-crjp-02-09-30

ISSN 2767-3278

(C)2021 Master Journals

Crossref do: 81 Google

Accepted 25th September, 2021 \& Published 30 ${ }^{\text {th }}$ September, 2021

system of physical culture and sports in rural areas, it can only be effective if it is constantly reformed and implemented on a regular basis. In particular, President Sh. M. In Mirziyoyev's words, "Life itself and the demands of the people set before us more and more complex tasks that need to be addressed in practice." [1] makes the development problem a necessity.

The purpose of the study is to identify current problems in the development of women athletes in rural areas, remote and remote areas of the country.

Research methods - questionnaires, analysis of scientific and methodological literature, study and generalization of best practices.

In the Republic of Uzbekistan, one of the priorities of state policy is to think about the fate of the nation, the future of the country, the development of its legal framework, the creation of the necessary conditions.

The family is a small but very important part of society. So, the future of the whole country depends on the children of this country. That is why the issue of a healthy generation has risen to the level of public policy.

The weight of the work done for the healthy birth, growth, education and development of our children is enormous. It is no coincidence that Uzbekistan ranks 9th among the countries that care about the health of the younger generation in the ranking of the international organization "Save the Children".

In our country, a comprehensive approach to the issue of a healthy child, a healthy generation. In other words, in order for a healthy child to be born, a great deal of attention is paid to the fact that the mother must first be healthy.

The role of sports in keeping mothers physically healthy is enormous. Therefore, special attention is paid to the development of women's sports in our country.
Today, the involvement of girls in sports has become widespread. To carry out this work, modern sports facilities have been built and are being built not only in the capital or in regional centers, but also in remote villages. They are equipped with sports equipment. Most importantly, the level of use of these sports facilities is growing from year to year.

As a result of such attention and care, our women are achieving high results at the Asian and World Championships and the Olympic Games in various sports.

Based on the purpose of our work, we conducted an online and offline survey of women to study the problems of the development of athletes among women living in rural areas, remote and remote areas of the country. The study involved 823 women living in rural, remote and remote areas of the country. Among the participants of the study, $57.5 \%$ were aged 18 to 35 years, and $42.5 \%$ were over 36 years old.

Do you think your region specializes in specific sports? $39.3 \%$ answered positively, $46.4 \%$ answered negatively and $14.3 \%$ could not answer.

Are there any conditions for sports in the area where you live? $44.9 \%$ answered positively, $46.4 \%$ answered negatively and $8.7 \%$ could not answer.

$97.4 \%$ of respondents said that sports play an important role in human health, while $2.3 \%$ said no. This difference in results is due to the fact that in certain areas women do not have enough information about sports, and in the area of residence women do not have the conditions for sports.

The development, popularization and transformation of physical culture and sports into a national movement in our country is an important factor in strengthening the health of citizens, the harmonious development of the 
CURRENT RESEARCH JOURNAL OF PEDAGOGICS 2(9): 136-141,

September 2021 DOI: https://doi.org/10.37547/pedagogics-crjp-02-09-30

ISSN 2767-3278

(C)2021 Master Journals

Crossref do: 81 Google

Accepted 25 $5^{\text {th }}$ September, 2021 \& Published $30^{\text {th }}$ September, 2021

younger generation. Therefore, in our country, special attention is paid to physical culture and sports as one of the important areas of state policy. Special attention is also paid to the development of women's sports, which aims to ensure the healthy birth, growth, upbringing and, ultimately, improvement of the nation's gene pool of children in Uzbekistan. $49.2 \%$ to $10-20 \%$, $32.2 \%$ to $30-50 \%, 15.2 \%$ to $50-70 \%$ and $2.2 \%$ to $70-100 \%$.

The construction of modern sports complexes in all regions of the country, including gymnasiums, tennis courts, swimming pools, fitness halls, where female coaches work, is an important factor in the popularity of sports among girls. Today, $65.5 \%$ of girls in the cities of the country and $52.7 \%$ in rural areas are involved in sports. This figure also testifies to the rapid development of women's sports in all regions of the country. This can be seen from the fact that $85.2 \%$ and $15.8 \%$ of the respondents had an idea of what sports they belong to in women's sports.
Today, in urban, rural, remote and remote areas of the country, special attention is paid to the transformation of physical culture and sports into a daily lifestyle for women through various health-improving events, competitions, tournaments, educational events. Ask yourself, "Do you play sports regularly?" 71.4\% answered positively, $17.5 \%$ answered negatively and $11.1 \%$ did not answer.

The sports environment formed in the family awakens the child's love for sports. Also, the organization of various sports clubs in schools will increase the interest of schoolgirls in sports and inspire love for sports. In addition to the sports fields organized in each neighborhood, the organization of sports clubs by female coaches will increase the number of girls.

Are your family members positive about your participation in sports? $82.6 \%$ answered positively, $9.4 \%$ answered negatively and $7.9 \%$ said they could not answer.

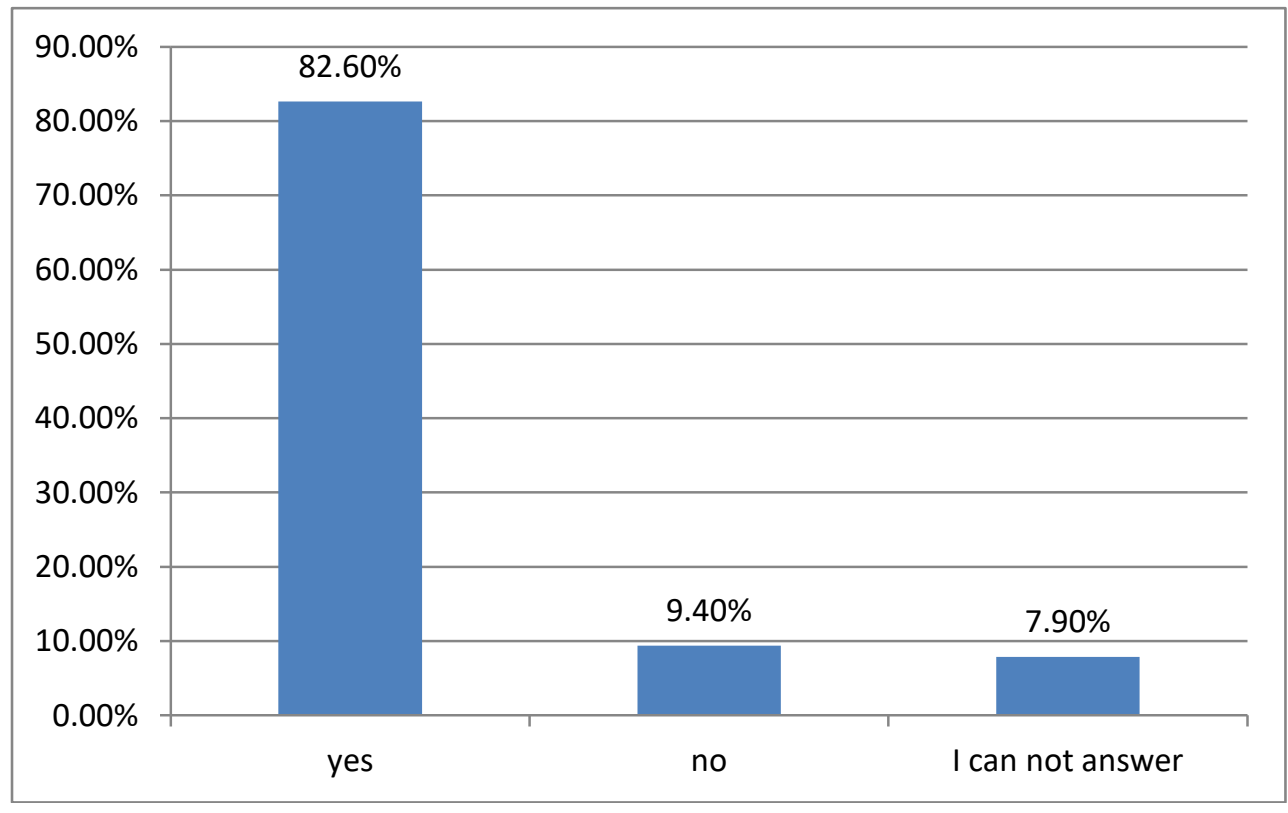


Respondents were asked, "Are you happy with the promotion of women's sports in your community?" 64\% answered positively, $21.7 \%$ answered negatively and $14.3 \%$ said they could not answer.

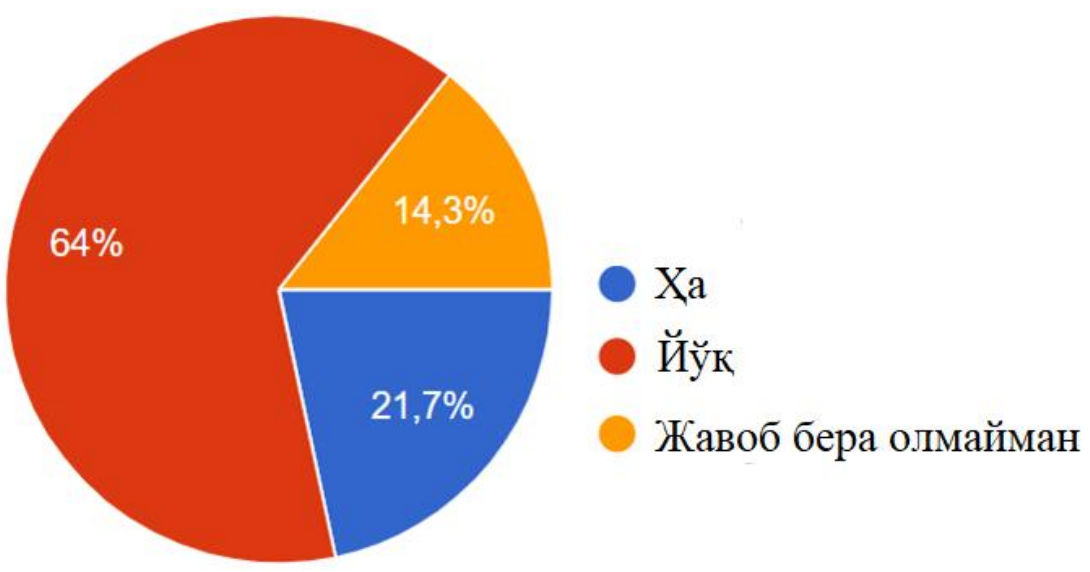

Also, do you agree with the principle of a healthy mother - a healthy child? 98\% said they were positive.

95.4\% of respondents said that sports play an important role in personal development, 2.3\% answered negatively and $2.1 \%$ said they could not answer, which is due to the lack of conditions for women's sports in remote villages.

It should be noted that the role of women's sports in the deeper and broader implementation of state programs, which are reflected in the documents on education, health, physical culture and sports, is invaluable in educating our youth spiritually and physically healthy.

One of the urgent tasks before us is to develop and popularize women's sports, to involve them more in healthy sports.

The organization of sports competitions for the purpose of mass physical culture and sports among women living in rural, remote and remote areas of the country increases the interest of our women in sports.

In particular, the number of women participating in sports events is growing every year as a result of intensive advocacy work in preschools and other sectors.

In our country, the full support of women, their care, social and legal assistance, raising their physical, spiritual and intellectual potential, directing girls to modern professions, their involvement in sports, the formation of a healthy family has risen to the level of state policy. .

To the question "Do you think that sports play an important role in preparing girls for marriage?", 86.8\% answered positively, 5.4\% answered negatively, and $7.8 \%$ said they could not answer. 
CURRENT RESEARCH JOURNAL OF PEDAGOGICS 2(9): 136-141,

September 2021 DOI: https://doi.org/10.37547/pedagogics-crjp-02-09-30

ISSN 2767-3278

(C)2021 Master Journals

Crossref do: 81 Google

Accepted 25 $5^{\text {th }}$ September, 2021 \& Published $30^{\text {th }}$ September, 2021

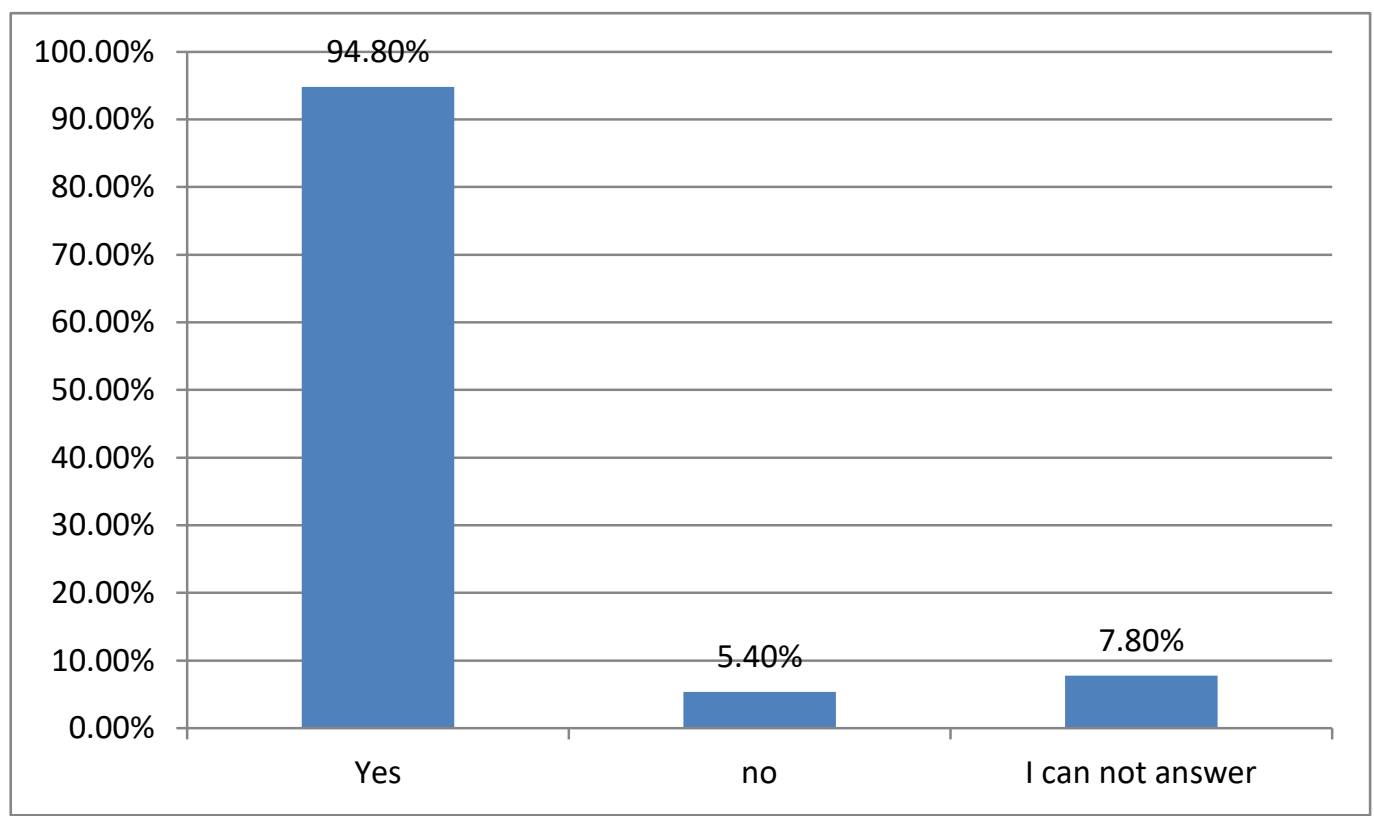

It should be noted that in preparing girls for marriage, along with the formation of healthy lifestyle habits in girls, they develop such high qualities as the formation of national and universal values, honesty, mutual respect respect, tolerance, aspiration to the goal. The formation of such values will further strengthen the links of society.

Given the wide range of opportunities for the development of women's sports in Uzbekistan, it is necessary to form the spiritual aspect of this area. For the development of girls' sports, it is necessary to take into account their place in society, their role in the family and the attitude to them in our values. It is known that the number of women engaged in physical culture and sports is growing from year to year. This fact testifies to the daily development of sports in our country and the positive changes taking place in our way of life.

Therefore, it is no coincidence that the fourth priority area of the "Strategy for further development of the Republic of Uzbekistan" for 2017-2021, focused on "Development of the social sphere", pays special attention to improving the science, education, literature, art and sports.

$94.4 \%$ of respondents said that they have enough information about the ongoing reforms in women's sports in the country.

It is no coincidence that the head of state said that "everyone should inculcate a culture of personal care for their health from a young age, with the help of family, school, neighborhood, health care, physical education and sports." After all, the program "People with healthy, educated and selfless children will surely build their future" is a program for us.

\section{Conclusion}

Along with the achievements, we must admit that we have a number of problems and challenges 
CURRENT RESEARCH JOURNAL OF PEDAGOGICS 2(9): 136-141,

September 2021 DOI: https://doi.org/10.37547/pedagogics-crjp-02-09-30

ISSN 2767-3278

(C)2021 Master Journals

Crossref do: 81 Google

Accepted 25th September, 2021 \& Published 30 ${ }^{\text {th }}$ September, 2021

ahead of us:

- Coordination of the activities of educational institutions, families, authorities in the development of women's sports in the community on the basis of a clear program of action;

-Introduction of sports instructors in the neighborhoods and planning, coordination and organization of sports competitions. There is an interest in sports in the neighborhood, identifying talented young people and directing them to the future;

- Involvement of the world's leading scientists and specialists in the process of professional development of female teachers and coaches in the field of sports.

In short, thanks to independence, women's sports are growing day by day due to the wide range of opportunities created. First of all, it serves to strengthen the health of our sisters, who will create the next generation, to form a healthy lifestyle among them, as well as in sports, our girls are achieving high results on world sports arenas and demonstrating what Uzbek women and girls are capable of.

\section{REFERENCES}

1. Decree of the President of the Republic of Uzbekistan Sh. Mirziyoyev dated February 7, 2017 "On the Strategy of Actions" for the further development of the Republic of Uzbekistan. T., People's Word newspaper, February 8, 2017, No. 28 (6722).

2. Decree of the President of the Republic of Uzbekistan dated February 2, 2018 No PF5325 "On measures to radically improve the activities in the field of support of women and strengthening the institution of the family."

3. Resolution of the President of the Republic of Uzbekistan dated June 27, 2018 No PP-3808 "On approval of the concept of strengthening the family in the Republic of Uzbekistan"

4. Abdullaev F.T. "Technical and tactical training of young boxers, taking into account the characteristics of the competition and training activities" Avtoreferat .Tashkent2009. 